Document downloaded from:

http://hdl.handle.net/10251/97791

This paper must be cited as:

Morales Torres, A.; Escuder Bueno, I.; Andrés Doménech, I.; SARA PERALES

MOMPARLER (2016). Decision Support Tool for energy-efficient, sustainable and integrated urban stormwater management. Environmental Modelling \& Software. 84:518-528.

doi:10.1016/j.envsoft.2016.07.019

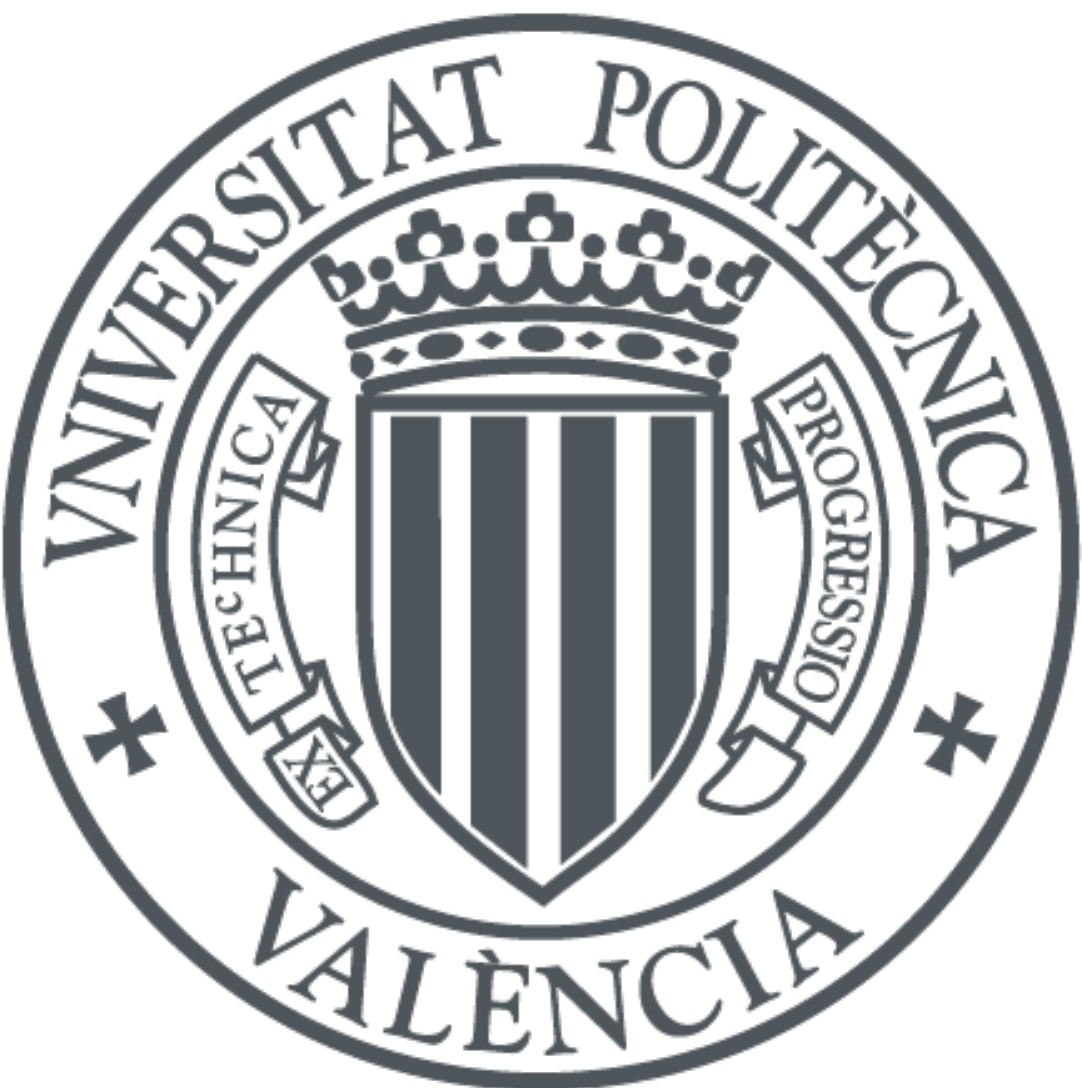

The final publication is available at

10.1016/j.envsoft.2016.07.019

Copyright Elsevier

Additional Information 


\title{
Decision Support Tool for energy-efficient, sustainable and integrated urban stormwater management
}

\author{
Adrián Morales-Torres ${ }^{1 *}$, Ignacio Escuder-Bueno ${ }^{1}$, Ignacio Andrés-Doménech ${ }^{1}$, Sara Perales- \\ Momparler $^{2}$ \\ ${ }^{1}$ Universitat Politècnica de València, Institute of Water and Environmental Engineering, \\ Valencia, Spain \\ ${ }^{2}$ PMEnginyeria, Valencia, Spain \\ *Corresponding author: \\ Address: Camino de Vera s/n 46022 Valencia (Spain) \\ Email:admotor@upvnet.upv.es Tel: +34637211465
}

\section{Highlights}

- The E2STORMED Decision Support Tool for stormwater management is presented.

- It complements financial analyses with energy and environmental criteria.

- It provides robust decision criteria for informed stormwater management.

- This tool encourages a more sustainable urban water management.

- The tool is very useful to promote SuDS between local and regional decision makers.

\begin{abstract}
The use of Sustainable Drainage Systems (SuDS) to manage urban runoff and contribute to environmental and landscape improvement is now widely known, but its application is still limited in many regions, like in Mediterranean countries. In addition, there is a lack of Decision Support Tools that consider all their benefits in the decision making process in a clear and integrated holistic way.

In this paper, the E'STORMED Decision Support Tool is presented. This tool analyses the impact of stormwater management in the urban environment and introduces energetic and environmental criteria in the decision making process. Therefore, it aims to fill in the existing "gap" between SuDS manuals and guidelines and regional and local decision makers, since it quantifies SuDS benefits and includes them in the comparison of different stormwater scenarios. Finally, the results of applying this tool to compare drainage infrastructures in a real urban development are described.
\end{abstract}

\section{Keywords}

Decision Support Tool; stormwater; Sustainable Drainage Systems (SuDS); urban water management; best management practices (BMPs); green infrastructure.

\section{Software availability}

The Decision Support Tool software presented in this paper can be freely downloaded in www.e2stormed.eu.

\section{Index}

1. Introduction 
2. Existing Decision Suport Tools for stormwater management

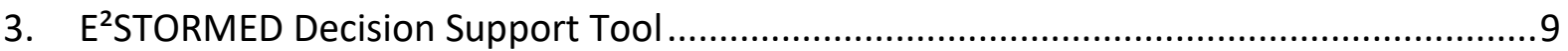

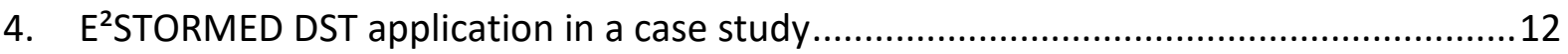

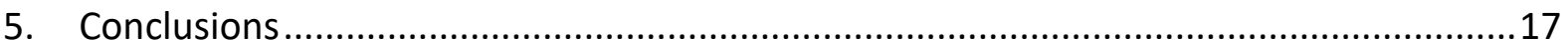

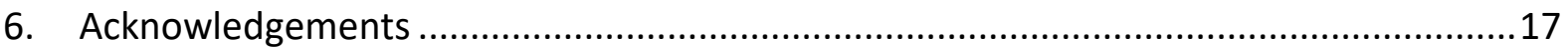

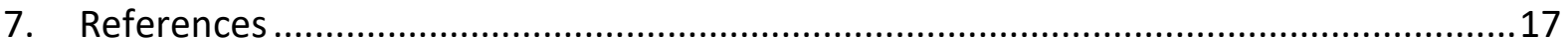

\section{INTRODUCTION}

Urban stormwater management is a complex subject, directly linked with other parts of the urban water cycle: management of one element (either good or bad) can influence the successful management of another (Ellis and Revitt, 2010; Philip, 2011). Since budgets are more and more limited and multiple stakeholders are involved, governance and planning are the key to promote a more sustainable development (McCormick et al., 2013). In this context, robust and transparent integrated decision criteria and methods for informed decisions will improve the quality of stormwater management.

In recent times Sustainable Drainage Systems (SuDS) are being promoted to achieve a more sustainable, integrated and flexible stormwater management. SuDS make use of common sense and simple technologies, embracing a broad range of typologies such as beds of native plants, rain barrels, green roofs and porous surfaces for car parking and roads (USEPA, 2012; Woods Ballard et al., 2015). The result is less water pollution from contaminated runoff, less flooding, less potable water use, replenished water supplies, and often more natural-looking, aesthetically pleasing cityscapes. Different terms are used worldwide to refer to sustainable stormwater management, such as low impact development, water sensitive urban design, best management practices (BMPs) and green infrastructure (Fletcher et al., 2014).

The principle of sustainable stormwater management changes the perception of stormwater from 'a nuisance that should be removed' to a 'resource that should be utilised' (Philip, 2011). The use of natural systems to attenuate runoff facilitates adaptation to climate change (Charlesworth, 2010) and international recommendations (EC, 2012; USEPA, 2008) have been developed to encourage the implementation of more sustainable, flexible and efficient drainage systems. Some of the main advantages of SuDS are (USEPA, 2012; CNT, 2010):

- Reducing discharge volumes translates into reduced Combined Sewer Overflows (CSO) and lower pollutant loads into the environment. CSO are produced when mixed waters are released into receiving water bodies during rainfall events because combined sewer systems does not have enough capacity, causing serious water pollution problems.

- Mitigating flood risk by slowing and reducing stormwater discharges.

- Reducing the use of potable water thanks to rainwater harvesting systems. This will reduce the costs and energy consumed in acquiring and treating drinking water. 
- Reducing the inflow of stormwater into sewer systems, hence reducing the costs and energy consumed in treating wastewater and pumping surface and foul water.

- Reducing local temperatures and shading of building surfaces. This will lessen the cooling and heating demand for buildings, reducing energy needs and decreasing emissions from power plants.

- Improving urban air quality by $\mathrm{CO}_{2}$ sequestration, reduction of particulate pollutants and ground level ozone reduction.

- Providing ecosystem services through habitat improvement, provision of recreation space and increment of properties value.

These benefits and advantages should be taken into account by decision makers when different stormwater management options are considered. Definitely, special attention should be paid to energy efficiency benefits, since water and wastewater facilities frequently represent the largest and most energy-intensive loads owned and operated by water utilities, representing up to $35 \%$ of municipal energy use (NRDC, 2009). Therefore, SuDS could really contribute to improve urban energy efficiency.

Recently, different technical manuals and guidelines have been produced about SuDS. They aim to assist the design of SuDS and to promote them between the decision makers and the population (CLADPW, 2010; CSQA, 2003; CP, 2008; NYSDEC, 2010; Puertas-Aguado et al., 2008; Woods Ballard et al., 2015; SFPUC, 2013; ARC, 2001). But still, there is a weak development of SuDS in many regions worldwide.

For instance, knowledge of sustainable stormwater management in the Mediterranean Region is limited to just a few countries. In addition, stormwater is treated reactively as a problem of waste and damage control, rather than proactively, as a resource. . The EU funded AQUAVAL project (Perales-Momparler et al., 2013) started to address these weaknesses by retrofitting seven new SuDS installations into two cities in Eastern Spain. During the project monitoring period, those SuDS achieved volume performances close to $100 \%$ (no runoff was spilled downstream). This efficiency was close to $90 \%$ for permeable pavements and slightly lower for green roofs. From a quality point of view, the pilots captured suspended solids, organic matter, nitrogen and phosphorus thus improving runoff quality and reducing pollutant loads reaching receiving waters (Perales-Momparler et al., 2014). These results show that SuDS can be very useful to reduce runoff volumes, peak flows and pollutants loads in Mediterranean stormwater management.

The EU-MED Programme $E^{2} S T O R M E D$ project (Improvement of energy efficiency in the water cycle by the use of innovative storm water management in smart Mediterranean cities, www.e2stormed.eu) capitalised on the AQUAVAL results and aimed to improve water management and energy efficiency in the urban water cycle and in buildings through the promotion of the use of SuDS in Mediterranean cities.

To meet these objectives, E2STORMED developed a Decision Support Tool (DST) to include energy efficiency and environmental criteria in urban stormwater management, so SuDS benefits are included in the decision making process. For this reason, the main intention of this tool is filling the existing "gap" between SuDS technical manuals and guidelines and regional and local decision makers and stakeholders. 
The main value of the $E^{2}$ STORMED DST is its holistic vision of urban stormwater management and its usefulness for decision makers to promote Sustainable Drainage Systems (SuDS). The tool is the result of a collaborative effort between academic and municipalities to identify the main issues and criteria that should play a role in stormwater decision making, defining the relations of stormwater management with water supply, wastewater management, energy consumption, urban ecosystems and urban development. Thus, the main scope of the paper is to explain the DST general structure and its holistic approach, although the detailed algorithms and equations used in each part can be found in (Morales-Torres et al., 2015).This tool was developed focusing on different case studies in Mediterranean countries, but data were drawn from international reference sources and as a result the tool can be used to support stormwater decision making worldwide.

This paper presents the structure and features of the E'2STORMED DST. First, a review of existing DSTs for stormwater management is made to justify the development of the $E^{2}$ STORMED DST. Second, the structure and methods of the E'STORMED DST are explained. Finally, the tool is applied to compare different drainage options for a new development in a Spanish Mediterranean city.

\section{EXISTING DECISION SUPORT TOOLS FOR STORMWATER MANAGEMENT}

Most of the existing software developed related with urban stormwater has been developed to estimate urban runoff and evaluate the stormwater infrastructures performance from a water quantity and/or quality point of view. Some examples of these designing tools are (USEPA, 2013a; VDCR, 2012; USEPA, 2013b; MW, 2010; Xpsolutions, 2015a; Xpsolutions, 2015b; DHI, 2015). Furthermore; most of these tools include a catalogue of SuDS that can be included in the urban drainage system design.

In this section, a review is made of existing DSTs to assist stormwater management. These tools do not (only) evaluate hydraulic performance of infrastructures, they also include additional information and/or procedures to support decision making. In summary, they estimate and/or compare costs, benefits and disadvantages of different stormwater options. In fact, most of the reviewed tools include some of the SuDS advantages described in the previous section.

In Table 1, the review of existing DSTs is summarized. Each tool is evaluated according to the following capabilities:

- Analysis of the infrastructure hydraulic performance for runoff quantity and quality management. Some tools include urban runoff estimations and analyze quantitatively or qualitatively how the stormwater infrastructures modify stormwater quality.

- Description and/or estimation of ecosystem services provided by drainage infrastructures. For instance, increased property values, habitat and biodiversity provision and recreational use.

- Estimation of costs, energy consumption and/or $\mathrm{CO}_{2}$ emissions for construction and maintenance of drainage infrastructures. Some tools include an estimation procedure based on other projects. 
- Estimation of costs, energy consumption and/or $\mathrm{CO}_{2}$ emissions of stormwater treatment and pumping.

- Estimation of flood protection, rainwater harvesting and building insulation improvement benefits and energy savings.

- Decision framework to compare advantages and disadvantages of different stormwater strategies. In general, Multi Criteria Analysis is usually used to compare different decision criteria. These techniques generally include the use of weighted and scored matrices, and hence require the establishment of measurable criteria, whether qualitative or quantitative, to assess the extent to which objectives may be fulfilled (UKEA, 2013). Some authors have already used these techniques to compare stormwater management options (Benzerra et al., 2012; Chow et al., 2013).

- Graphical interface and results provided to support decision making. Results should be attractive and easy to understand by stakeholders.

This list of capabilities has been selected according to the expected costs, benefits advantages and disadvantages of stormwater strategies that should be considered for a sustainable and energy-efficient stormwater management.

The North Carolina State University Rainwater harvesting model (NCSU, 2009) is a simple tool focused on cost and benefits of rainwater harvesting systems. This model uses rainfall data and anticipated usage to establish cisterns inputs and outputs.

The Water Environment Research Federation BMP and LID Whole Life Cost Model (WERF, 2009 ) is a series of spreadsheets, each of which is specific to one SuDS technique. It provides detailed analysis of capital costs, maintenance and whole life costs for a number of common SuDS techniques. Costs are derived by inputting specific details including design and maintenance hydraulic design.

Center for Neighborhood Technology Green Values (CNT, 2009) is an online tool for comparing the performance, costs, and benefits of two infrastructures scenarios: SuDS development and conventional stormwater practices. The user has to introduce rainfall and drainage area data, while the tool estimates costs and benefits of drainage infrastructures based on data from similar projects.

The COFAS Tool (Peters, C.; Sieker, H.; Jin, Z; Eckart, J, 2010) is a DST which allows comparison of a range of stormwater strategies through a Multi Criteria Analysis framework. This framework assesses the flexibility of the different options compared. Decision criteria can be chosen by the user, but, for each option, decision criteria data (costs, water quality, runoff production, etc.) should be introduced.

Key Performance Indicators (KPI) developed by (Chow et al., 2013) is not a tool but a methodology to compare stormwater strategies, including sustainable designs benefits, with a Multi Criteria decision framework. Nevertheless it includes procedures to quantify most of the SuDS benefits, like energy savings, rainwater harvesting benefits, reduction of carbon emissions, etc. This methodology could be included within software to be used by regional and municipal entities for decision making.

SuDS For Roads (SEPA, 2013) is a spreadsheet that can be used to estimate whole life costing and whole life carbon emissions of drainage infrastructures. These results can be 
used as part of the stormwater selection criteria to provide evidence to support the appropriate selection of SUDS in roads.

SUSTAIN model (USEPA, 2013b) is a software model that provides process-based simulation of flow and pollutant behavior for a wide range of structural SuDS. It is focused on stormwater water quality processes, although it also provides data to estimate drainage infrastructures costs.

UKSuDS (HR Wallingford, 2013) is a group of tools to advise developers with choosing suitable SuDS components, assessing the water quality treatment effectiveness and obtaining indicative costs of these infrastructures. These tools are based on United Kingdom data and they provide independent results, but there is not a global framework to compare different drainage strategies with their results.

Water Sensitive Urban Design in Sydney (WSUD, 2015) developed a Decision Support Matrix to compare different options for stormwater projects. This matrix is a Multi Criteria Analysis implemented in a spreadsheet that compares infrastructures costs with water quality, water quantity, environmental, social and institutional benefits. This matrix should be populated by the user with data from hydraulic and water quality models.

Construction Industry Research and Information Association developed a spreadsheet called BeST (CIRIA, 2015) that provides a structured approach to economically evaluate a wide range of social and ecosystem services provided by drainage infrastructures. All these benefits are used to compare different drainage scenarios in a period of time. It also lists potential stakeholders to be taken into account when each expected benefit is evaluated.

Finally, New York City developed the online tool Co-Benefits Calculator (NYC, 2015) for stormwater evaluation and planning purposes. This calculator tool identifies co-benefits associated with each type of SuDS and calculates environmental, social, and economic costs and benefitsIt was developed based on monitoring data from different SuDS in New York.

As can be observed in Table 1, there is a wide diversity of DSTs for stormwater management, from tools that only address the estimation of construction and maintenance costs to tools that are focused in the comparison of different strategies. But, there is not any integrated tool that estimates the costs, benefits, advantages and disadvantages of each strategy and uses these results in a Multi Criteria Analysis to support the decision making process.

Furthermore, some of the benefits related with sustainable stormwater management are not estimated in most of the tools, like those of building insulation improvements and savings in stormwater treatment and pumping. In spite of the high energy consumption in urban water management, very few tools include energy criteria to compare different drainage strategies.

In addition, some of the tools are very focused on local data for a specific country or region, what makes them less useful to be applied anywhere.

In conclusion, a new tool is needed to integrate all the costs and benefits related with stormwater management. It should not only be focused on infrastructure construction and maintenance but also consider stormwater treatment and pumping costs, rainwater harvesting benefits, ecosystem services, energy efficiency improvements, flood protection benefits, water quality processes and building insulation benefits. Furthermore, this tool 
should also include these results in a Multi Criteria Analysis framework in order to assist decision makers towards sustainable stormwater management. 


\begin{tabular}{|c|c|c|c|c|c|c|c|c|c|c|}
\hline VCSU & $\begin{array}{l}\text { WERF } \\
2009\end{array}$ & $\begin{array}{l}\text { CNT } \\
2009\end{array}$ & $\begin{array}{l}\text { Peters } \\
\text { et al. } \\
2010\end{array}$ & $\begin{array}{l}\text { Chow } \\
\text { et al. } \\
2013\end{array}$ & $\begin{array}{r}\text { SEPA } \\
2013\end{array}$ & $\begin{array}{c}\text { USEPA } \\
2013 b\end{array}$ & $\begin{array}{c}\text { HR } \\
\text { Wallingford } \\
2013\end{array}$ & $\begin{array}{c}\text { WSUD } \\
2015\end{array}$ & $\begin{array}{l}\text { CIRIA } \\
2015\end{array}$ & $\begin{array}{l}\text { NYC } \\
2015\end{array}$ \\
\hline
\end{tabular}

Analysis of stormwater infrastructures performance

Estimates runoff production

Estimates rainwater harvesting

water savings

Analyses stormwater quality

Analyses ecosystems services provided

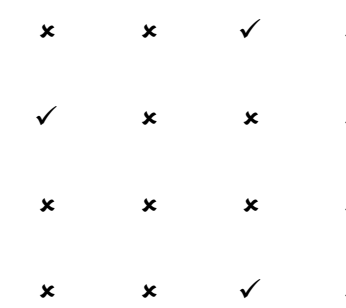

\begin{tabular}{|c|c|c|c|c|c|c|c|c|c|c|c|}
\hline \multicolumn{12}{|c|}{ Cost and benefits estimation } \\
\hline $\begin{array}{l}\text { Estimates construction and } \\
\text { maintenance costs }\end{array}$ & $\checkmark$ & $\checkmark$ & $\checkmark$ & $x$ & $\checkmark$ & $\checkmark$ & $\checkmark$ & $\checkmark$ & $x$ & $x$ & $\checkmark$ \\
\hline $\begin{array}{l}\text { Estimates stormwater pumping } \\
\text { and treatment costs }\end{array}$ & $x$ & $x$ & $\checkmark$ & $x$ & $\checkmark$ & $x$ & $x$ & $x$ & $x$ & $\checkmark$ & $\checkmark$ \\
\hline $\begin{array}{l}\text { Estimates flood protection } \\
\text { benefits }\end{array}$ & $x$ & $x$ & $x$ & $x$ & $\checkmark$ & $x$ & $x$ & $x$ & $x$ & $\checkmark$ & $x$ \\
\hline $\begin{array}{l}\text { Estimates benefits of building } \\
\text { insulation improvement }\end{array}$ & $x$ & $x$ & $x$ & $x$ & $x$ & $x$ & $x$ & $x$ & $\checkmark$ & $\checkmark$ & $x$ \\
\hline
\end{tabular}
insulation improvement

Estimates energy consumption and emissions during

construction and maintenance Estimates energy consumption and emissions of stormwater pumping and treatment

Estimates energy savings due to rainwater harvesting

Estimates energy savings of building insulation

improvement

Estimates $\mathrm{CO}_{2}$ sequestration by vegetation

\section{Energy consumption and emissions estimations}

\begin{tabular}{|c|c|c|c|c|c|c|c|c|c|c|c|}
\hline \multicolumn{12}{|c|}{ Results to support stormwater decision making } \\
\hline $\begin{array}{l}\text { Analyses total costs and } \\
\text { benefits for each stormwater } \\
\text { strategy }\end{array}$ & $\checkmark$ & $\checkmark$ & $\checkmark$ & $x$ & $\checkmark$ & $\checkmark$ & $\checkmark$ & $\checkmark$ & $\checkmark$ & $\checkmark$ & $\checkmark$ \\
\hline $\begin{array}{l}\text { Obtains energetic and } \\
\text { environmental criteria }\end{array}$ & $x$ & $x$ & $x$ & $x$ & $\checkmark$ & $\checkmark$ & $x$ & $x$ & $\checkmark$ & $\checkmark$ & $\checkmark$ \\
\hline Makes a multi-criteria analysis & $x$ & $x$ & $x$ & $\checkmark$ & $\checkmark$ & $x$ & $x$ & $x$ & $\checkmark$ & $x$ & $x$ \\
\hline \multicolumn{12}{|c|}{ Software characteristics } \\
\hline $\begin{array}{l}\text { Has a simple and easy graphical } \\
\text { interface }\end{array}$ & $\checkmark$ & $\checkmark$ & $\checkmark$ & $\checkmark$ & $x$ & $x$ & $x$ & $\checkmark$ & $x$ & $x$ & $\checkmark$ \\
\hline $\begin{array}{l}\text { Provides simple and easy } \\
\text { understable results }\end{array}$ & $\checkmark$ & $\checkmark$ & $\checkmark$ & $\checkmark$ & $x$ & $\checkmark$ & $\checkmark$ & $\checkmark$ & $\checkmark$ & $\checkmark$ & $\checkmark$ \\
\hline
\end{tabular}

Table 1. Review of existing Decision Support Tools to support stormwater management. 


\section{E'STORMED DECISION SUPPORT TOOL}

The main objective of the $E^{2}$ STORMED DST is to include energy efficiency and environmental criteria in the urban stormwater management, promoting innovative sustainable solutions. This tool quantifies the economic costs, savings, energy consumption and $\mathrm{CO}_{2}$ emissions of different drainage scenarios in order to include them in a Multi Criteria Analysis to choose between them. Figure 1 shows the general concept of this tool.

The $E^{2}$ STORMED DST includes a catalogue of more than 20 types of drainage infrastructures, including SuDS, which are used to define the different drainage scenarios to be compared. For each scenario, costs, benefits, advantages and disadvantages are analyzed to be compared in a Multi Criteria Analysis.

Initially, life cycle costs, energy consumptions and $\mathrm{CO}_{2}$ emissions of drainage infrastructures can be estimated based on international literature and guidelines. Unitary construction and maintenance costs are obtained from (Royal Haskoning DHV, 2012; CNT, 2009; SFPUC, 2013; SCSMC, 2010). More accurate data can be introduced to produce a construction budget and a maintenance plan according to local conditions. Unitary data to compute energy consumptions and $\mathrm{CO}_{2}$ emissions of construction and maintenance is also obtained from international references (ICE, 2011; ITeC, 2013; SEPA, 2013). Life cycle costs, energy consumption and emissions are computed, taking into account the lifespan of each infrastructure.

Next, annual runoff volume in each scenario can be calculated. The $E^{2}$ STORMED DST includes a simple rainfall-runoff model (USDA, 1986) and international data about runoff volume reduction in drainage infrastructures (USEPA, 2012; ISBMPD, 2011). These results can be replaced with more detailed data from other hydraulic models. Furthermore, the number and annual volume of expected CSO in each scenario can be introduced to be used as quantitative criteria.

Afterward, stormwater treatment and pumping costs, energy consumption and $\mathrm{CO}_{2}$ emissions are estimated. Pumping energy requirements are analyzed with hydraulic equations. Treatment cost and energy requirements are assessed based on international data for combined (wastewater treatment) and separated systems (Molinos Senante, 2012; CNT, 2009).

Next, rainwater harvesting economic and energetic benefits are estimated. Firstly, energy consumption and $\mathrm{CO}_{2}$ emissions in the acquisition, distribution and treatment of drinking water are assessed based on international data (IDA, 2012; Singh, 2011; WEF, 2010) and hydraulic equations to estimate pumping energy requirements. This computation of energy consumptions and emissions includes water losses due to leakages in the network, since they play a relevant role in water supply systems (Puleo et al., 2015). Secondly, rainwater reuse volume is estimated with a monthly water balance based on local rainfall data and water demands. Finally, these results are combined to estimate energy savings and benefits of rainwater harvesting.

Flood protection benefits of drainage infrastructures (DEFRA, 2009) are estimated using Frequency-Damages (FD) curves for pluvial events (Escuder-Bueno et al., 2011). These curves show the annual exceedance probability (inverse of return period) of each event versus its flood economic consequences. Flood protection benefits can be estimated 
comparing the situation with and without the drainage infrastructure. Average economic damages per property can be estimated using international data (NFIP, 2013).

In addition, economic and energetic benefits of building insulation improvement provided by green roofs are addressed. These benefits are estimated with a one-dimensional heat flux model (Diaz and Tenorio, 2005), based on building use and local temperatures. The effect of the green roof in building insulation has been estimated based on (Hui, 2009).

Next, $\mathrm{CO}_{2}$ sequestration by vegetation included in the drainage infrastructures is also estimated. This estimation is made based on the number of trees and the vegetated area in each drainage strategy (Akbari, 2002).

Stormwater quality processes are analyzed qualitatively because of its complexity. The user has to evaluate a runoff water quality performance for three different groups of pollutants: suspended soils, nutrients and heavy metals. This estimation is made based on the number of infrastructures in the management train and the estimated pollutant capacity removal of each infrastructure typology, according to guidelines and recommendations (Woods Ballard et al., 2015). If a more complex model was used to evaluate water quality or local data from similar sites, these results could be introduced as quantitative criteria in the Multi Criteria analysis.

Ecosystems services provided by the drainage infrastructure are also analyzed qualitatively. In each scenario, a global value of ecosystem services should be selected by the user according to that provided by each infrastructure typology. Some of the ecosystem services evaluated are increased property values, habitat and biodiversity provision, air quality improvement, regulation of urban micro-climates, noise reduction and recreational use (Wade, 2013).

With all these results, the $E^{2}$ STORMED DST computes time graphs, which represent the results of costs, energy consumption and emissions obtained for each scenario, representing them cumulatively during the analyzed period. These graphs are obtained by adding costs, benefits, energy consumption and emissions in infrastructure lifecycle, water reuse, runoff pumping and treatment, flood protection and building insulation.

Finally, quantitative and qualitative criteria are obtained from the previous analysis to populate a simple Multi Criteria Analysis (UKEA, 2013). The user has to choose the decision criteria from the previous results and their weights in order to obtain a global score for each scenario. Moreover, other quantitative and/or qualitative criteria can be added to the analysis such as social preferences or political aspects. Multi Criteria Analysis results are shown in circular and bar graphs.

The $E^{2}$ STORMED DST is an integrated tool that is not only focuses on drainage infrastructures construction and performance, but also takes into account the impacts of the stormwater management in other fields like water supply (rainwater reuse), wastewater treatment (in combined systems), urban energy management and urban planning (flood protection and ecosystem services). Consequently, it addresses all the issues listed in Table 1.

This tool has a clear and simple graphical interface (Figure 2), to allow the user to introduce the available data easily for each scenario. It also provides default data when local specific data are not available, so it can be used for analysis of different levels of detail. Results from other more complex hydraulic tools can be an input in the E$^{2}$ STORMED DST. In addition, the 
tool is flexible enough to be used at different scales, from very few households to large urban areas.

Within the E'STORMED project, this tool was applied in six pilot Mediterranean municipalities: Benaguasil (Spain), Pisa (Italy), Zabbar (Malta), Hersonissos (Greece), Zagreb (Croatia) and Cetinje (Montenegro). The data and results of this application were used to improve the tool default data and methods. Local stakeholders and managers have actively participated in the tool development at identifying potential impacts of stormwater management in other fields and proposing useful decision criteria for stormwater decision makers.

This DST has been mainly developed with data from Mediterranean cities and international guidelines, but it is flexible enough to be applied for stormwater management worldwide, since most of the input data can be customized according to local conditions. Detailed explanation of the data and methods used in each part of the DST can be found in the DST Guidelines (Morales-Torres et al., 2015).

Finally, future upgrades of the tool will consider how input data uncertainty and climate change effects influence the results of the Multi Criteria Analysis, since these effects could change runoff production and rainwater harvesting processes (Liuzzo et al., 2016).

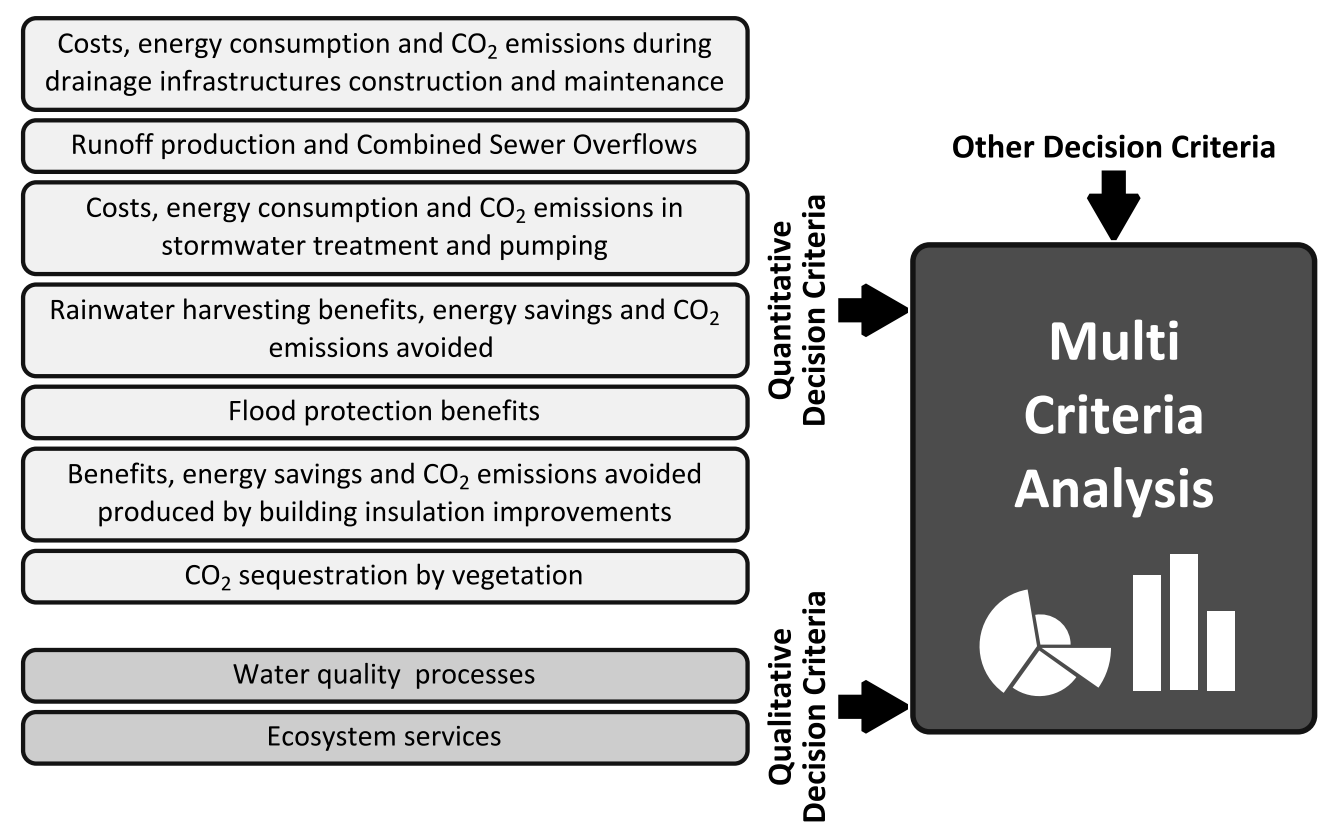

Figure 1. Conceptual scheme of the E2STORMED Decision Support Tool. 


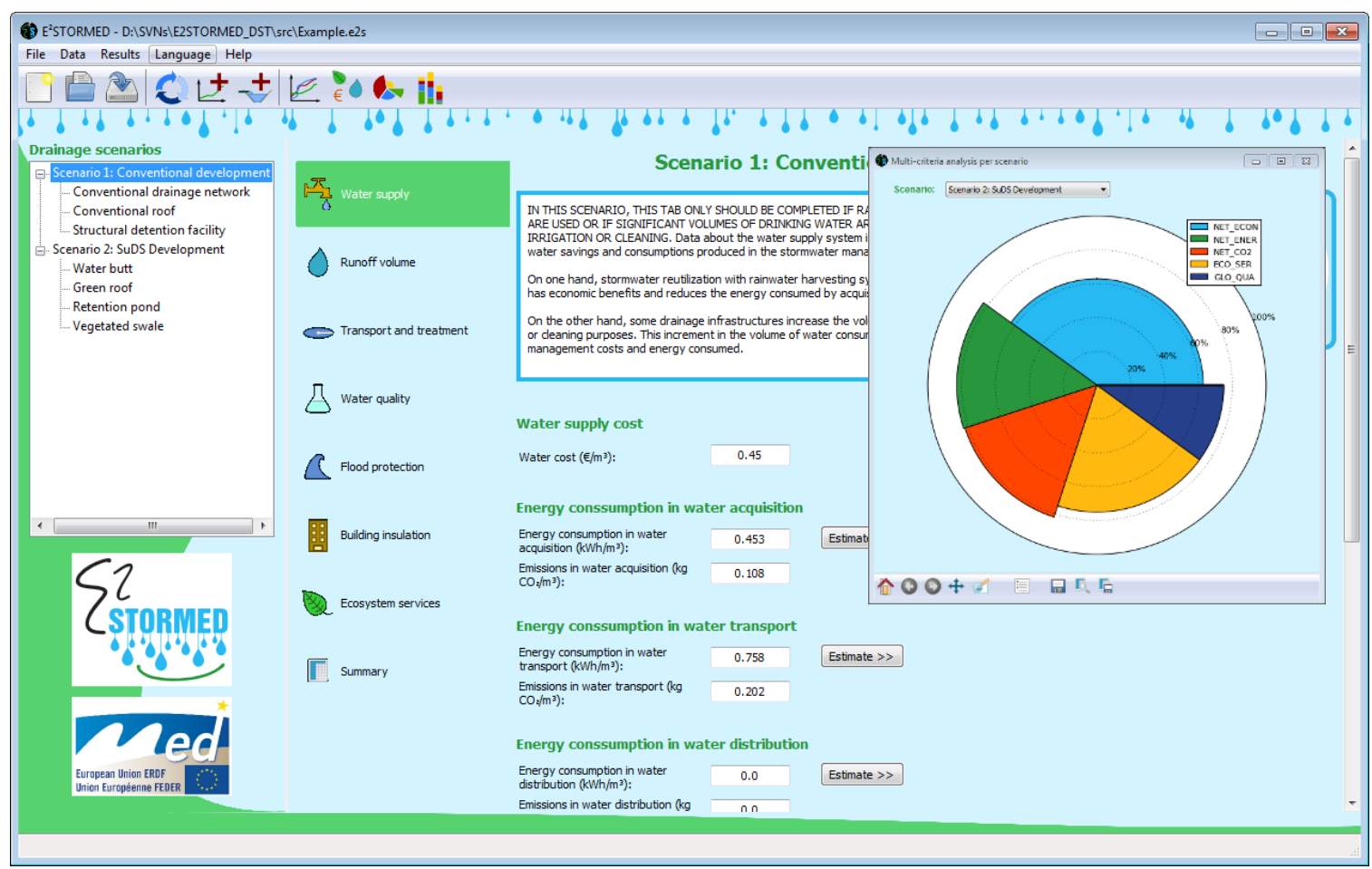

Figure 2. Graphical Interface of the Decision Support Tool.

\section{4. $E^{2}$ STORMED DST APPLICATION IN A CASE STUDY}

In order to illustrate the use of the E'STORMED DST, the tool was applied to inform stormwater management for a new real urban development in Benaguasil, a Mediterranean city in Spain. In recent years, this municipality has begun a transition towards more sustainable stormwater management, integrating the views and strategies from different actors (Perales-Momparler et al., 2015). For this reason, the E²STORMED DST is a useful tool to quantify and disseminate the benefits of SuDS, strengthening this transition process.

The new development is detailed in the Urban Plan of the municipality and it includes households (expected population: 1840 inhabitants) and public buildings with small green areas. The total area is $387741 \mathrm{~m}^{2}$. This development will include a separated drainage system, whose main objective will be preserving drainage patterns (quantity and quality) to protect receiving water bodies. Therefore, this new development should not increase runoff peaks and pollutants load downstream.

Two potential drainage scenarios were compared for stormwater management using the E2STORMED DST: a conventional approach and a SuDS approach. These two scenarios can be observed in detail in Figure 3. In order to design these two scenarios, a maximum outflow of $650 \mathrm{l} / \mathrm{s}$ was considered for the discharge to the outflow channel, due to its limited capacity. This is the main "anchor point" for the design and comparison of both scenarios: two drainage solutions that have a proper performance without surface floods for the design storm (15 year return period $+10 \%$ increase to account for climate change following the recommendations from (Willems et al., 2012; Rodríguez et al., 2013)).

In the conventional scenario, a drainage network is proposed with pipes, curbs and gutters. This separated network would collect stormwater from the urban area and direct it to a detention basin at the end. This facility is necessary to store stormwater for a short period 
of time so runoff peaks can be reduced to avoid challenging the receiving channel during severe rainfall events. Due to the fact that the invert level of the channel is much deeper than the base of the detention basin, a pumping station is required to empty it after each storm.

In the SuDS scenario, the main objective of this solution is to preserve the original drainage patterns in terms of quantity and quality. The proposed solution is a combination of a green roof on a public building, rain gardens in the residential lots and public built up areas, permeable pavement in public parking lots, 2 underground cisterns for rainwater harvesting, bioretention areas located along the roads, separated drainage pipes (collect stormwater from the urban area to the vegetated swale), a vegetated swale (conveys water from the separate network to the downstream infiltration basin) and an infiltration basin. In this case, SuDS located at source will drastically reduce flows and runoff volume; hence a smaller and shallower detention facility will be needed at the end of the piped system. In addition, as they provide water treatment, runoff that reaches the end of pipe structure can be infiltrated, avoiding the need of a pumping station. The stormwater management train in this scenario is shown in detail in Figure 4.
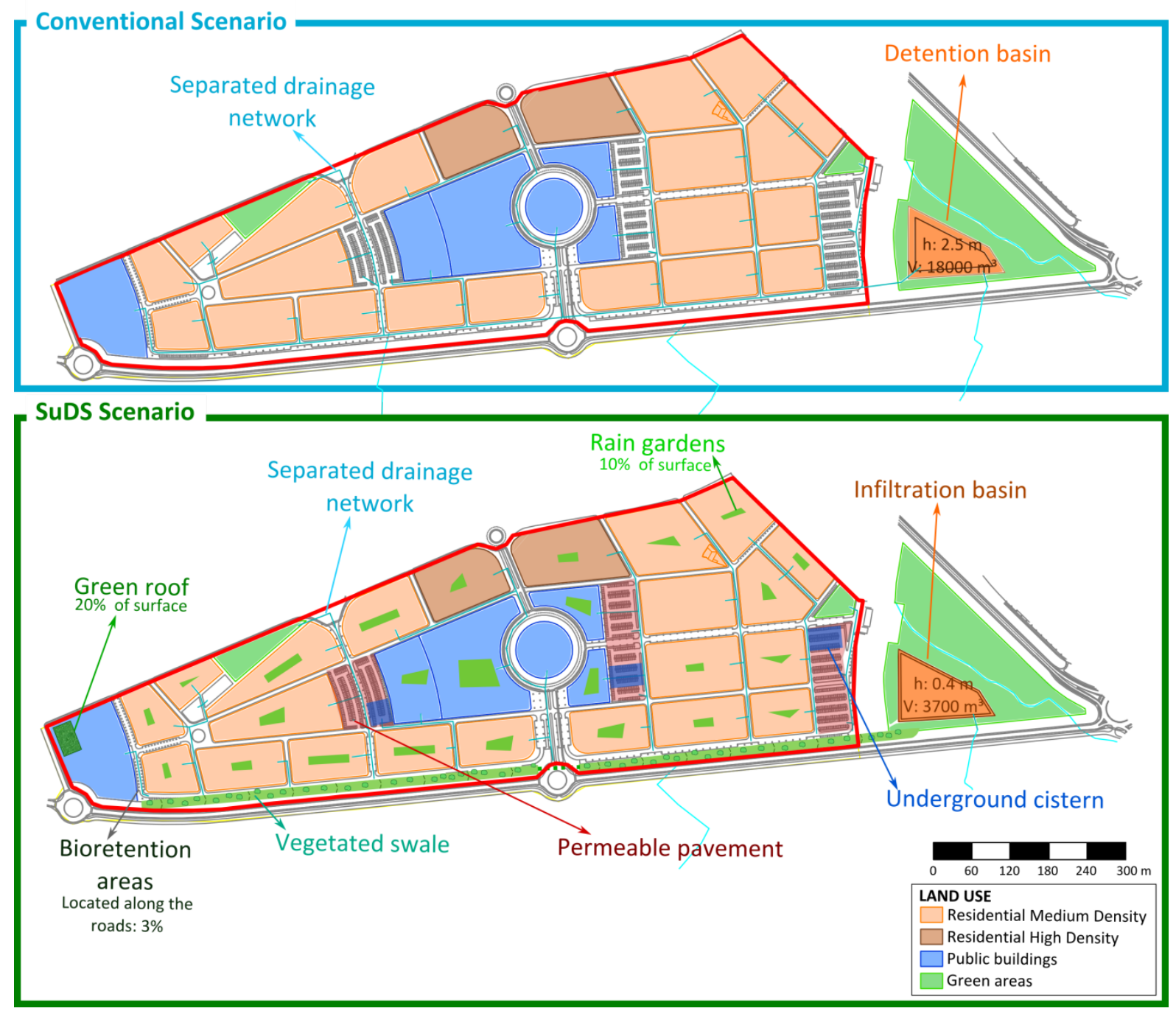

Figure 3. Scenarios compared in the case study.

Hydraulic performance in both scenarios to fulfill with decision criteria has been analyzed with the Microdrainage software (Xpsolutions, 2015b). Hydraulic performance has been 
checked for the design storm and in a continuous analysis made using the rainfall data for 2007 (year with higher intensity events). It has been checked that in both scenarios the outflow is lower than $650 \mathrm{l} / \mathrm{s}$. Results of runoff and infiltration annual volumes from this hydraulic analysis were used as an input for the E²STORMED DST.

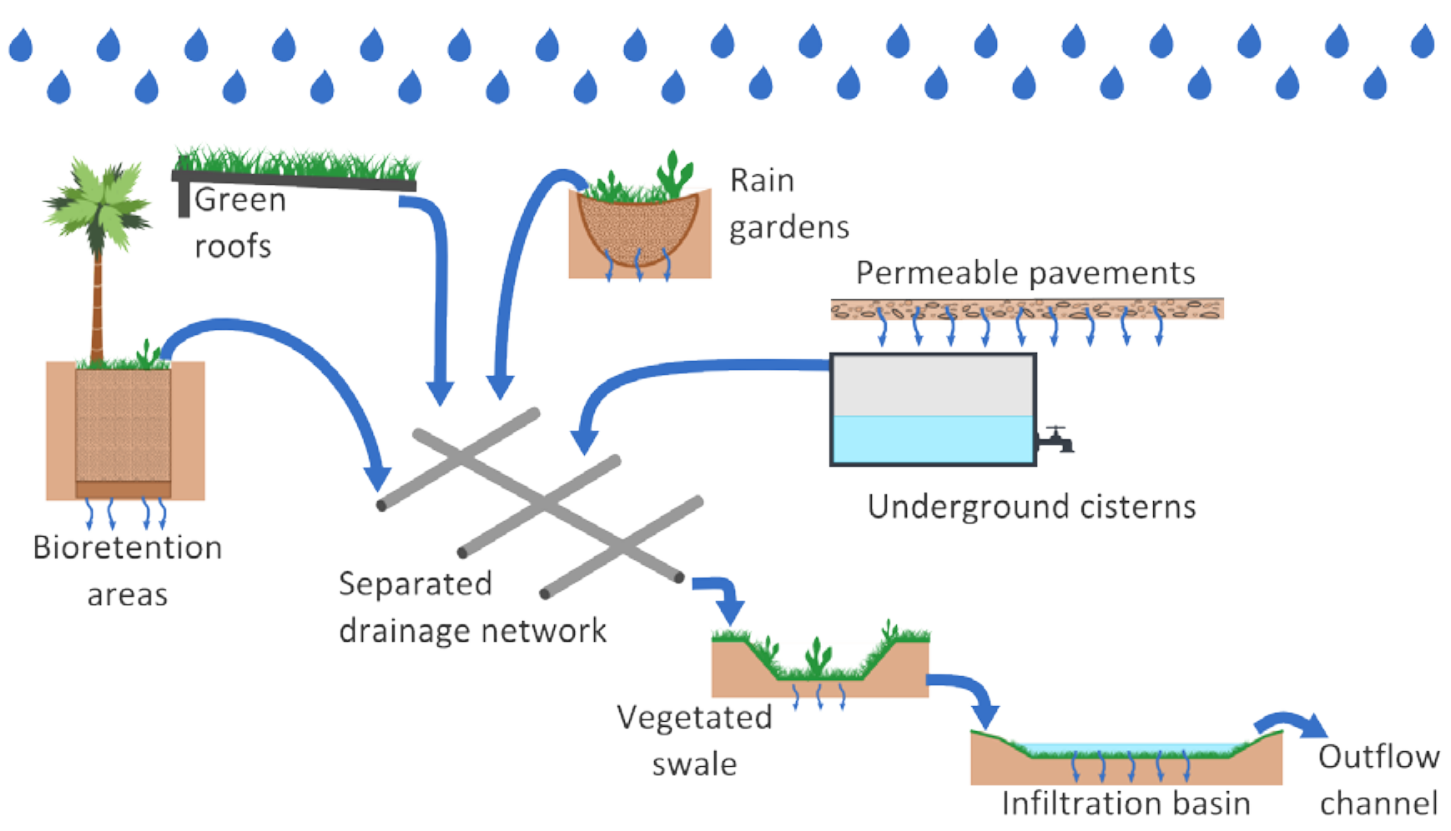

Figure 4. Stormwater management train in SUDS scenario.

For each scenario the costs, benefits, energy consumption and $\mathrm{CO}_{2}$ emissions were estimated for construction and maintenance of infrastructure, stormwater treatment and pumping, rainwater harvesting, building insulation improvement and carbon sequestration by vegetation. They were computed using the methods and default values provided by the DST and explained in the previous section.

Costs, energy consumption and emissions were compared for both scenarios using the $E^{2}$ STORMED DST. Results are shown in Figure 5. In this comparison, a period of analysis of 50 years was considered and a discount rate of $3 \%$ was used to compute the present value of costs and benefits. As shown in these graphs, the second option has lower energy consumptions and emissions in all the analyzed period. In contrast, it has higher costs in most of the period due to the higher maintenance costs, while the construction cost of both scenarios are very similar. 


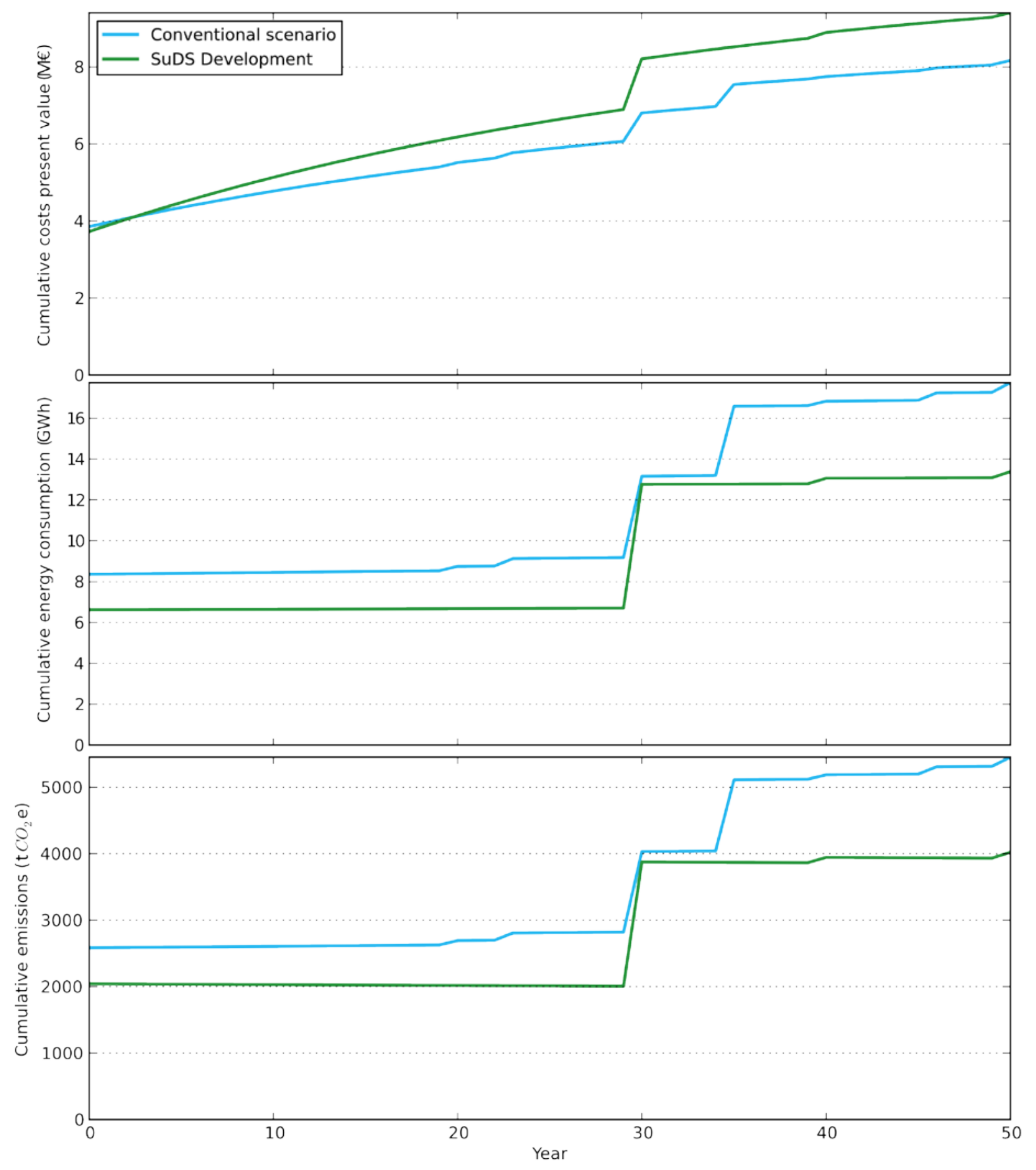

Figure 5. Variation of costs present value, energy consumption and emissions during the period of analysis in the two scenarios.

Finally, these results were used to compute decision criteria and inform decision making using the DST. These criteria were chosen with the participation of key stakeholders related with water, energy and urban planning management in the municipality. Being a new development, costs are not as important as in a retrofitting scenario, since new urban areas are being built. In contrast, outflow water quality is really significant, since outflow runoff is directly discharged into the drainage channel connected with sensitive water bodies. Hence, selected decision criteria were:

- Net cost of stormwater management (total present value of stormwater management cost obtained adding costs of infrastructures construction and 
maintenance and runoff treatment and conveyance minus benefits produced by water reuse and building insulation): Weight $10 \%$.

- Net energy consumed by stormwater management (total stormwater management energy consumed obtained adding energy consumed by infrastructures' construction and maintenance and runoff treatment and conveyance minus energy saved by water reuse and building insulation): Weight $25 \%$.

- Net emissions of stormwater management (total stormwater management $\mathrm{CO}_{2}$ emissions obtained adding emissions of infrastructures construction and maintenance and runoff treatment and conveyance minus emissions saved by water reuse and building insulation): Weight $5 \%$.

- Global outflow water quality (protection of receiving water bodies): Weight $35 \%$.

- Volume of water reused (optimization of drinking water use): Weight $10 \%$.

- Aquifer recharge: Weight $5 \%$.

- Landscaping integration of infrastructures and educational opportunities: Weight $10 \%$.

These criteria were computed and combined in a Multi Criteria Analysis using the $E^{2}$ STORMED DST, whose results are shown in Figure 6. They show that the SuDS scenario should be recommended since it has better scores in most of the criteria selected for the comparison. This result highlights that using SuDS in new developments will produce a better and more energy-efficient stormwater management in this municipality.

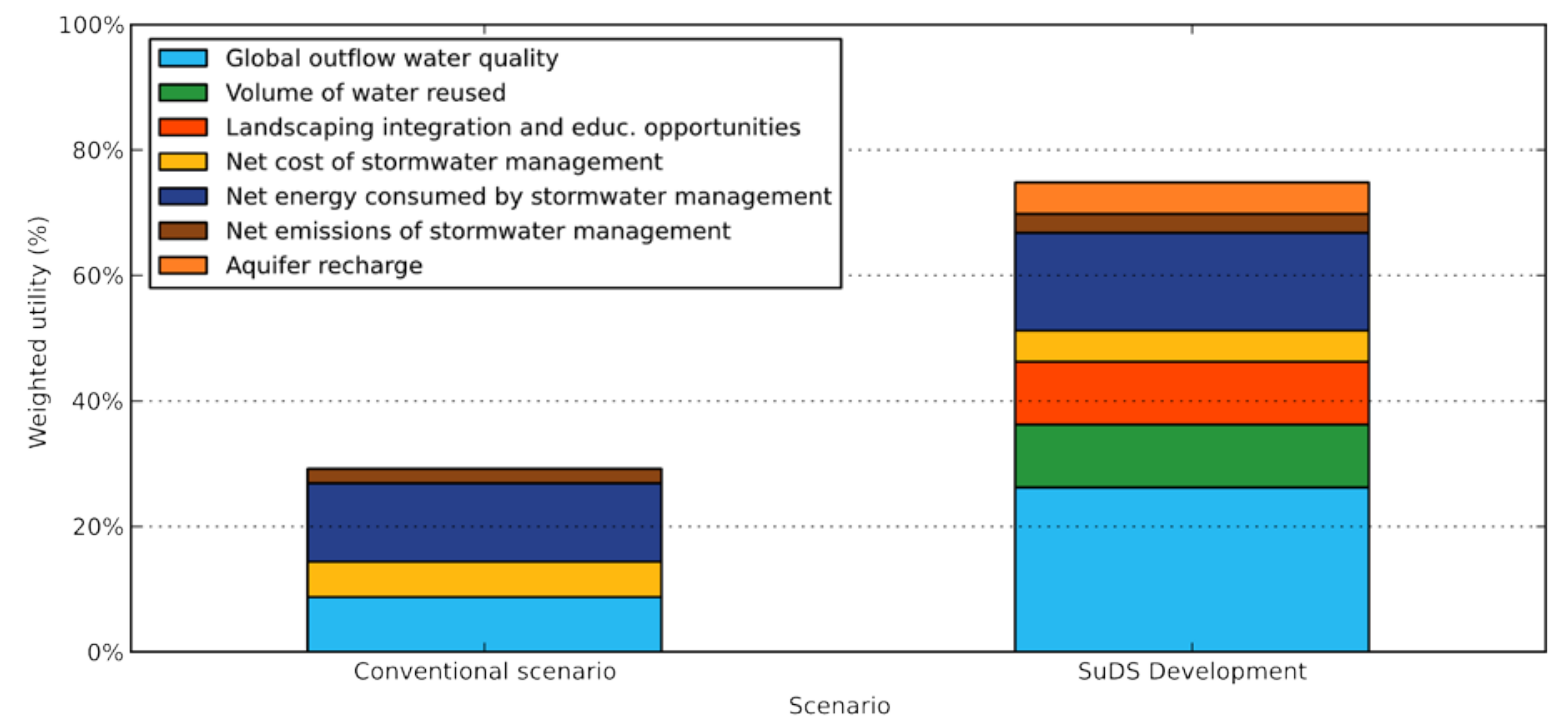

Figure 6. Comparison of the Multi Criteria analysis results for the two scenarios. 


\section{CONCLUSIONS}

Nowadays, there is a clear trend towards more sustainable stormwater management and urban development. Hence, energetic, social and environmental criteria should be involved in the decision making process.

In fact, in recent years different tools have been developed to inform urban stormwater management. Most of them include environmental and social criteria in the decision making process and promote the use of SuDS. Although these tools are a good beginning, a more integrated tool is needed to analyze the effects of stormwater management in the whole urban water cycle and urban development.

In this paper, the $E^{2}$ STORMED DST is presented. This tool complements financial analyses of stormwater management projects with energy and environmental criteria with the aim of more sustainable urban water management. The tool provides robust and transparent decision criteria and methods for informed stormwater management.

The $E^{2}$ STORMED DST is an integrated tool that not only focuses on drainage infrastructure construction and performance, but also takes into account the impacts of stormwater management in other fields like water supply, wastewater treatment, urban energy management and urban planning. These results are used to compare different drainage scenarios using a simple Multi Criteria Analysis.

In conclusion, this tool can be very useful to promote SuDS between local and regional decision makers, since it introduces their economic, energetic and environmental benefits in the decision making framework. It provides simple, clear and quantitative results which are necessary to fill the existing "gap" between SuDS technical manuals and guidelines and regional and local decision makers and stakeholders.

\section{ACKNOWLEDGEMENTS}

The E2STORMED project (Reference: 1C-MED12-14), within which the Decision Support Tool described in this paper has been developed, was funded by the MED Programme of the European Union. Authors would also like to express their gratitude to the $E^{2}$ STORMED project partners for their assistance and collaboration in this work.

\section{REFERENCES}

Akbari, H. (2002). 'Shade trees reduce building energy use and CO2 emissions from power plants', Environmental Pollution, vol. 116, pp. 119 - 126.

ARC (2001). Georgia Stormwater Management Manual - Volume 2. [Online] Atlanta Regional Commission. Available at: http://documents.atlantaregional.com/gastormwater/GSMMVol2.pdf [Accessed 6 May 2013].

Benzerra, A., Cherrared, M., Chocat, B., Cherqui, F. and Zekiouk, T. (2012). 'Decision support for sustainable urban drainage system management: A case study of Jijel, Algeria', Journal of Environmental Management, vol. 101, pp. 46 - 53. 
Charlesworth, S.M. (2010). 'A review of the adaptation and mitigation of global climate change using sustainable drainage in cities', Journal of Water and Climate Change, vol. 1, no. 3, pp. 165-180.

Chow, J., Savić, D., Fortune, D., Kapelan, Z. and Mebrate, N. (2013). 'Using a systematic, multi-criteria decision support framework to evaluate sustainable drainage designs', 12th International Conference on Computing and Control for the Water Industry, CCWI2013, Perugia (Italy), 343 - 352.

CIRIA (2015). Susdrain - BeST (Benefits of SuDS Tool). Construction Industry Research and Information Association, [Online]. Available: http://www.susdrain.org/resources/best.html [11 Nov 2015].

CLADPW (2010). Stormwater Best Management Practice Design and Maintenance Manual For Publicly Maintained Storm Drain Systems. [Online] County of Los Angeles Department of Public Works.. Available at: http://dpw.lacounty.gov/ldd/publications/Stormwater\%20BMP\%20Design\%20and\%20Main tenance\%20Manual.pdf [Accessed 21 May 2013].

CNT (2009). Green values - National Stormwater Management Calculator. Center for Neighborhood Technology, [Online]. Available: http://greenvalues.cnt.org/national/calculator.php [11 Nov 2015].

CNT (2010). The Value of Green Infrastructure - A Guide to Recognizing Its Economic, Environmental and Social Benefits. [Online] Center for Neighborhood Technology - American Rivers. Available at: http://www.cnt.org/sites/default/files/publications/CNT Value-ofGreen-Infrastructure.pdf [Accessed 11 Nov 2015].

CP (2008). Portland Stormwater Management Manual. [Online] City of Portland. Available at: http://www.portlandoregon.gov/bes/47952 [Accessed 20 May 2013].

CSQA (2003). Stormwater Best Management Practice Handbook. [Online] California Stormwater Quality Association. Available at: http://www.cabmphandbooks.com/ [Accessed 18 Jun 2013].

DEFRA (2009). Impact Assessment - Local Flood Risk Management and the increased use of Sustainable Drainage systems. [Online] Department for Environment Food and Rural Affairs United Kingdom. Available at: http://archive.defra.gov.uk/environment/flooding/documents/policy/fwmb/fwmialocalfm.p df [Accessed 8 May 2013].

DHI (2015). MIKE URBAN. [Online] Danish Hydraulic Institute Group. Available at: http://www.mikepoweredbydhi.com/products/mike-urban [Accessed 11 Nov 2015].

Diaz, M.I. and Tenorio, J.A. (2005). Pérdidas de calor y formación de condensaciones en los puentes térmicos de los edificios, Instituto de Ciencias de la Construcción Eduardo Torroja.

EC (2012). Guidelines on best practice to limit, mitigate or compensate soil sealing. [Online] European Commission. Available at: http://ec.europa.eu/environment/soil/pdf/guidelines/pub/soil en.pdf [Accessed 14 May 2013].

Ellis, J.B. and Revitt, D.M. (2010). Stormwater as a Valuable Resource Within the Urban Water Cycle. [Online] SWITCH Project. Sustainable Water Management in the City of the 
Future. Available at: http://www.switchurbanwater.eu/outputs/pdfs/W22 CBIR RPT D2.2.4a Stormwater as a valuable resource within the urban water cycle .pdf [Accessed 14 May 2013].

Escuder-Bueno, I., Morales-Torres, A., Castillo-Rodríguez, J.T. and Perales-Momparler, S. (2011). SUFRI Methodology for pluvial and river flooding risk assessment in urban areas to inform decision-making. [Online] 2nd ERA-NET CRUE Research Funding Initiative Flood resilient communities - managing the consequences of flooding. Available at: http://www.crue-eranet.net/Calls/Methodology Risk Assessment.pdf [Accessed 08 May 2013].

Fletcher, T.D., Shuster, W., Hunt, W.F., Ashley, R., Butler, D., Arthur, S., Trowsdale, S., Barraud, S., Semadeni-Davies, A., Bertrand-Krajewski, J., Mikkelsen, P.S., Rivard, G., Uhl, M., Dagenais, D. and Viklander, M. (2014). 'SUDS, LID, BMPs, WSUD and more - The evolution and application of terminology surrounding urban drainage', Urban Water Journal, pp. 1 17.

HR Wallingford (2013). UK SuDS Tools Website, [Online]. Available: www.uksuds.com [11 Nov 2015].

Hui, S.C.M. (2009). Study of Thermal and Energy Performance of Greenroof Systems, Department of Mechanical Engineering. The University of Hong Kong.

ICE (2011). The Inventory of Carbon and Energy, United Kingdom: Institution of Civil Engineers.

IDA (2012). Desalination Yearbook 2010-2011. [Online] International Desalination Association. Available at: http://www.idadesal.org/publications/ida-desalination-yearbook/ [Accessed July 2013].

ISBMPD (2011). Technical Summary: Volume Reduction. [Online] International Stormwater Best Management Practices (BMP) Database. Available at: http://www.bmpdatabase.org/Docs/Volume\%20Reduction\%20Technical\%20Summary\%20J an\%202011.pdf [Accessed 26 Jun 2013].

ITeC (2013). MetaBase Construmática. Institut de Tecnologia de la Construcció de Calalunya, [Online]. Available: http://www.construmatica.com/bedec [11 Nov 2015].

Liuzzo, L., Notaro, V. and Freni, G. (2016). 'A Reliability Analysis of a Rainfall Harvesting System in Southern Italy', Water, vol. 8, no. 18, pp. 1-20.

McCormick, K., Anderberg, S., Coenen, L. and Neij, L. (2013). 'Advancing sustainable urban transformation', Journal of Cleaner Production, vol. 50, pp. 1 - 11.

Molinos Senante, M. (2012). Eficiencia económica en estaciones depuradoras de aguas residuales: una medida para reducir los costes de operación, Valencia: Diazotec. ISBN: 97884-939470-8-8.

Morales-Torres, A., Jefferies, C., Perales-Momparler, S. and Berwick, N. (2015). E'STORMED Decision Support Tool Guidelines. [Online] E'STORMED Project. MED Programme. Available at: www.e2stormed.eu.

MW (2010). MUSIC Guidelines. Recommended input parameters and modelling approaches for MUSIC users. [Online] Melbourne: Melbourne Water. Available at: 
http://www.melbournewater.com.au/Planning-and-building/Forms-guidelines-andstandard-drawings/Documents/MUSIC-tool-guidelines.pdf [Accessed 11 Nov 2015].

NCSU (2009). Rainwater Harvesting. North Carolina State University, [Online]. Available: http://www.bae.ncsu.edu/topic/waterharvesting/model.html [2013 Jun 26].

NFIP (2013). The cost of flooding. National Flood Insurance Programa. U.S. Department of Homeland Security, 25 Apr, [Online]. Available: http://www.floodsmart.gov/floodsmart/pages/flooding flood risks/the cost of flooding.js p [8 May 2013].

NRDC (2009). Water Efficiency Saves Energy: Reducing Warming Pollution Through Water Use Strategies. [Online] Natural Resources Defense Council. Available at: http://www.nrdc.org/water/files/energywater.pdf [Accessed 11 Nov 2015].

NYC (2015). New York City Green Infrastructure Co-Benefits Calculator. New York City, [Online]. Available: http://www.nycgicobenefits.net/ [11 Nov 2015].

NYSDEC (2010). Stormwater Management Design Manual. [Online] New York State Department of Environmental Conservation. Center for Watershed Protection. Available at: http://www.dec.ny.gov/chemical/29072.html [Accessed 17 Jun 2013].

Perales-Momparler, S., Andrés-Doménech, I., Andreu, J. and Escuder-Bueno, I. (2015). 'A regenerative urban stormwater management methodology: the journey of a Mediterranean city', Journal of Cleaner Production, pp. 1 - 16.

Perales-Momparler, S., Hernández-Crespo, C., Vallés-Morán, F., Martín, M., AndrésDoménech, I., Andreu-Álvarez, J. and Jefferies, C. (2014). 'SuDS Efficiency during the StartUp Period under Mediterranean Climatic Conditions', CLEAN Soil Air Water, vol. 42, no. 2, pp. 178-186.

Perales-Momparler, S., Jefferies, C., Perigüell-Ortega, E., Peris-García, P.P. and MuñozBonet, J.L. (2013). 'Inner-city SUDS retrofitted sites to promote sustainable stormwater management in the Mediterranean region of Valencia: AQUAVAL (Life+ EU Programme)', 8e Conférence Internationale NOVATECH, Lyon (France).

Peters, C.; Sieker, H.; Jin, Z; Eckart, J (2010). Assessing future uncertainties associated with urban drainage using flexible systems - the COFAS method and tool. [Online]. Available at: http://www.switchurbanwater.eu/outputs/pdfs/W2-

1 GEN MAN D2.1.4 Assessing future uncertainties urban drainage COFAS.pdf [Accessed 11 Nov 2015].

Philip, R. (2011). Module 4. Stormwater- Exploring the options. SWITCH Training Kit. Integrated urban water management in the city of the future. [Online] SWITCH Project. ICLEI European Secretariat GmbH. Available at: http://www.switchtraining.eu/modules/module4/\#c68 [Accessed 6 May 2013].

Puertas-Aguado, J., Suárez-López, J. and Anta-Álvarez, J. (2008). Gestión de las aguas pluviales: implicaciones en el diseño de los sistemas de saneamiento y drenaje urbano, Madrid: CEDEX, Centro de Estudios Hidrográficos. Ministerio de Fomento, Ministerio de Medio Ambiente y Medio Rural y Marino. España. 
Puleo, V., Sambito, M. and Freni, G. (2015). 'An Environmental Analysis of the Effect of Energy Saving, Production and Recovery Measures on Water Supply Systems under Scarcity Conditions', Energies, vol. 8, pp. 5937-5951.

Rodríguez, R., Navarro, X., Casas, M.C., Ribalaygua, J., Russo, B., Pougetd, L. and Redaño, A. (2013). 'Influence of climate change on IDF curves for the metropolitan area of Barcelona', International Journal of Climatology, vol. 34, no. 3, pp. 643-654.

Royal Haskoning DHV (2012). Costs and Benefits of Sustainable Drainage Systems. [Online] Royal Haskoning DHV. Committee on Climate Change. Available at: http://hmccc.s3.amazonaws.com/ASC/2012\%20report/Royal\%20Haskoning\%20Costs\%20an d\%20Benefit\%20of\%20SuDS\%20Final\%20Report.pdf [Accessed 20 May 2013].

SCSMC (2010). Low Impact Development Manual for Southern California. [Online] Southern California Stormwater Monitoring Coalition. Available at: https://www.casqa.org/LID/SoCalLID/tabid/218/Default.aspx [Accessed 20 May 2013].

SEPA (2013). SUDS for Roads - Whole Life Cost and Whole Life Carbon tool. [Online] Scottish Environment Protection Agency. Available at: http://www.sepa.org.uk/water/water regulation/regimes/pollution control/suds/suds wo rking party/whole life cost and whole life.aspx [Accessed 02 Sep 2013].

SFPUC (2013). Stormwater Design Guidelines. San Francisco Public Utility Comission, [Online]. Available: http://www.sfwater.org/index.aspx?page=446 [20 Jun 2013].

Singh, R. (2011). 'Analysis of energy usage at membrane water treatment plants', Desalination and Water Treatment, pp. 63-72.

UKEA (2013). Multi Criteria Analysis (MCA). [Online] United Kingdom Environment Agency. Available at: http://www.environment-agency.gov.uk/research/policy/32929.aspx [Accessed 15 Nov 2014].

USDA (1986). Urban Hydrology for Small Watersheds. [Online] United States Department of Agriculture. Natural Resources Conservation Service. Available at: http://www.hydrocad.net/pdf/TR-55\%20Manual.pdf [Accessed 20 Jun 2013].

USEPA (2008). Managing wet weather with green infrastructure. Action Strategy 2008, United States Environmental Protection Agency.

USEPA (2012). National Menu of Stormwater Best Management Practices. United States Environmental Protection Agency, 3 Apr, [Online]. Available: http://cfpub.epa.gov/npdes/stormwater/menuofbmps/index.cfm [26 Jun 2013].

USEPA (2013a). Storm Water Management Model (SWMM). United States Environmental Protection Agency, 1 Feb, [Online]. Available: http://www.epa.gov/nrmrl/wswrd/wq/models/swmm/ [20 Jun 2013].

USEPA (2013b). SUSTAIN. System for Urban Stormwater Treatment and Analysis IntegratioN Model. United States Environmental Protection Agency., 20 May, [Online]. Available: http://www.epa.gov/nrmrl/wswrd/wq/models/sustain/ [18 Jun 2013].

VDCR (2012). Runoff Reduction Method. Virginia Department of Conservation and Recreation, 29 Nov, [Online]. Available:

http://www.dcr.virginia.gov/laws and regulations//r2f.shtml [20 Jun 2013]. 
Wade, R. (2013). A Critical Review of Urban Diffuse Pollution Control: Methodologies to Identify Sources, Pathways And Mitigation Measures With Multiple Benefits. [Online] Centre of Expertise for Waters (CREW). Available at: http://nora.nerc.ac.uk/502913/1/CREW Diffuse Pollution Stage3 BGS ReportFinal.pdf [Accessed 11 Nov 2015].

WEF (2010). Energy conservation in water and waste water facilities., New York: Water Environment Federation Press. McGrawHill.1st ed.

WERF (2009). BMP and LID Whole Life Cost Models: Version 2.0. Water Environment Research Federation. [Online]. Available at: http://www.werf.org/i/a/Ka/Search/ResearchProfile.aspx?Reportld=SW2R08 [Accessed 11 Nov 2015].

Willems, P., Olsson, J., Arnbjerg-Nielsen, K., Beecham, S., Pathirana, A., Bülow Gregersen, I., Madsen, H. and Nguyen, V.T.V. (2012). Impacts of Climate Change on Rainfall Extremes and Urban Drainage Systems, IWA Publishing.

Woods Ballard, B., Wilson, S., Udale-Clarke, H., Illman, S., Scott, T., Ashley, R. and Kellagher, R. (2015). The SuDS Manual. [Online] Construction Industry Research and Information Association. Available at: http://www.ciria.org/Resources/Free publications/SuDS manual C753.aspx [Accessed 19 Apr 2016].

WSUD (2015). Decision Support Tool. Water Sensitive Urban Design in Sydney, [Online]. Available: http://www.wsud.org/resources-examples/tools-resources/decision-supporttool/ [11 Nov 2015].

Xpsolutions (2015a). Xpdrainage. Quickly Design, Compare and Analyse Stormwater Controls, [Online]. Available: http://xpsolutions.com/Software/XPDRAINAGE/ [11 Nov 2015].

Xpsolutions (2015b). Microdrainage. Drainage Design Software. [Online]. Available at: http://xpsolutions.com/Software/MICRO-DRAINAGE/ [Accessed 11 Nov 2015]. 